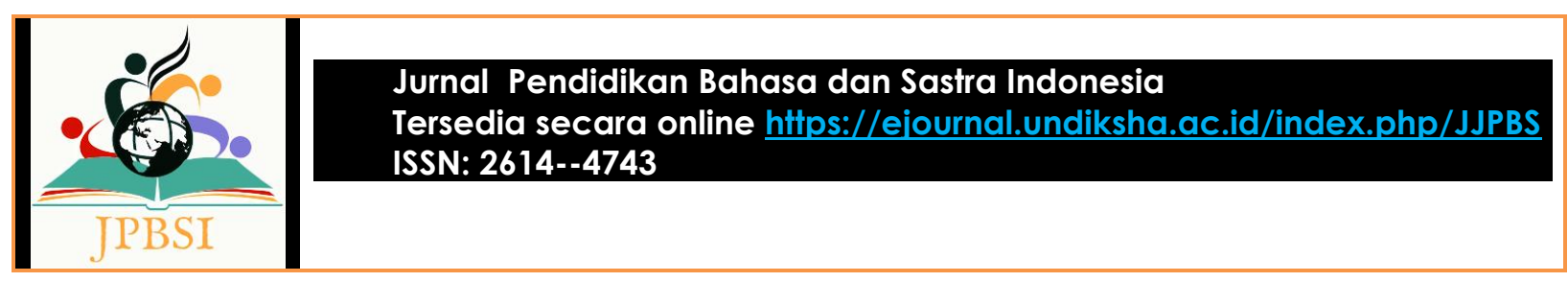

\title{
PEMBELAJARAN BAHASA INDONESIA PADA MASA PANDEMI COVID-19 DI SMP LAB UNDIKSHA SINGARAJA
}

\author{
Desy Febri Lestari \\ Program Studi Pendidikan Bahasa Indonesia, Universitas Pendidikan Ganesha \\ Singaraja, Bali, Indonesia
}

Surel: desyfebrilestari21@undiksha.ac.id

\begin{tabular}{|c|c|}
\hline \multicolumn{2}{|r|}{ Abstrak } \\
\hline $\begin{array}{l}\text { Kata Kunci: Masa } \\
\text { Pandemi; } \\
\text { Pembelajaran Bahasa } \\
\text { Indonesia; } \\
\text { Pembelajaran Daring }\end{array}$ & $\begin{array}{l}\text { Penelitian ini bertujuan untuk mengetahui pembelajaran Bahasa Indonesia pada masa } \\
\text { pandemi Covid-19 di SMP Lab Undiksha Singaraja. Penelitian ini berjenis deskriptif } \\
\text { dengan menggunakan pendekatan kualitatif. Subjek dalam penelitian ini adalah siswa } \\
\text { kelas XI-1 dan guru Bahasa Indonesia. Objek penelitian ini disesuaikan dengan } \\
\text { rumusan masalah pada penelitian, yaitu pembelajaran Bahasa Indonesia pada masa } \\
\text { pandemi Covid-19 di SMP Lab Undiksha. Metode dalam penelitian ini yakni metode } \\
\text { observasi, metode wawancara, metode dokumentasi, dan metode angket. Pembelajaran } \\
\text { daring yang telah dilaksanakan sangatlah berbeda dengan pembelajaran sebelum } \\
\text { pandemi terjadi. Hal ini terlihat dari cara mengajar yang dulunya tatap muka sekarang } \\
\text { berlangsung secara tanpa tatap muka. Hasil penelitian ini menunjukkan bahwa } \\
\text { pembelajaran Bahasa Indonesia pada masa pandemi Covid-19 di SMP Lab Undiksha } \\
\text { walaupun fasilitas dan penunjang yang memadai tidak membuat pembelajaran luput } \\
\text { dari kendala yang bermunculan. }\end{array}$ \\
\hline \multicolumn{2}{|r|}{ Abstract } \\
\hline $\begin{array}{l}\text { Keywords: Pandemic } \\
\text { Period; Learning } \\
\text { Indonesian; Learning, } \\
\text { During }\end{array}$ & $\begin{array}{l}\text { This study aimed to determine the learning of Indonesian during the Covid-19 pandemic } \\
\text { at SMP Lab Undiksha Singaraja. The research was a descriptive type using a } \\
\text { qualitative approach. The subjects in this study were students of class XI-1 and Mrs. Ni } \\
\text { Wayan Seriati, S.Pd. The object of this research is adjusted to the formulation of the } \\
\text { problem in the research, namely learning Indonesian during the Covid-19 pandemic at } \\
\text { the Undiksha Lab Middle School. The methods in this study are the observation method, } \\
\text { the interview method, the documentation method, and the questionnaire method. The } \\
\text { online learning that has been carried out is very different from the learning before the } \\
\text { pandemic occurred. This can be seen from the way of teaching that used to be face-to- } \\
\text { face now takes place withoutface-to-face. The results of this study indicate that learning } \\
\text { Indonesian during the Covid-19 pandemic at the Undiksha Lab Junior High School, } \\
\text { although adequate facilities and support do not make learning free from emerging } \\
\text { obstacles. }\end{array}$ \\
\hline $\begin{array}{l}\text { Diterima/direview/ } \\
\text { dipublikasi }\end{array}$ & 6 Agustus 2021/ 20 Agustus 2021/ 30 September 2021 \\
\hline
\end{tabular}

PENDAHULUAN

Pandemi ini membuat masyarakat di seluruh dunia harus berdiam diri di rumah, melakukan pekerjaan dari rumah, bersekolah dari rumah, dan aktivitas lainnya wajib dikerjakan dari rumah. Hal ini membuat banyak sekolah ditutup dan Belajar Dari Rumah (BDR). Indonesia sudah menerapkan Work From Home (WFH), Belajar Dari Rumah (BDR), dan kegiatan lainnya sejak pertengahan Maret dan hingga saat ini masyarakat diwajibkan menggunakan masker saat bepergian, berjaga jarak terhadap individu lainnya saat berinteraksi dan dan rajin

Banyak sekolah hingga perguruan tinggi yang sudah melaksanakan BDR sesuai dengan "SE Sekertaris Jendral Nomor 15 Tahun 2020 Berkaitan dengan panduan dalam terlaksananya BDR ketika 


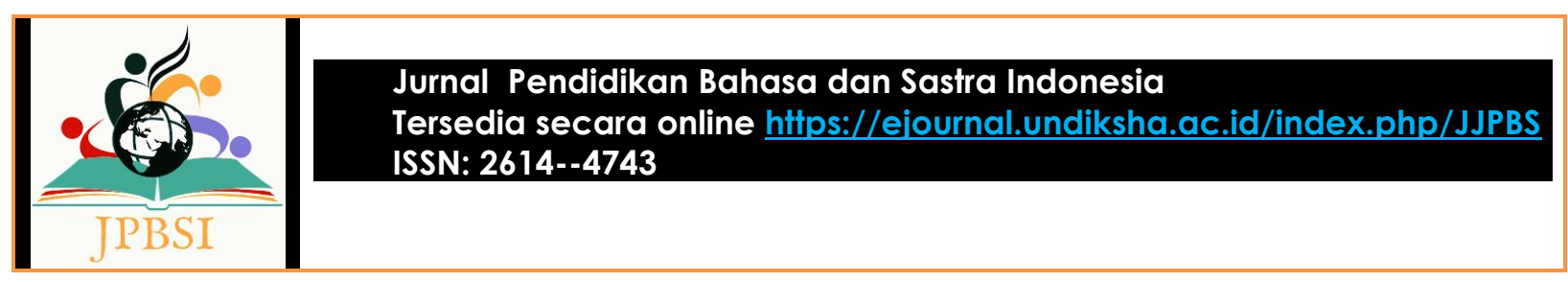

darurat Covid-19" di mana diterbitkan oleh Kemendikbud. Sasaran pelaksanaan BDR ialah mencukupi segala hak siswa dalam memperoleh pelayanan dalam bidang pendidikan ketika pandemi Covid-19 dan juga terlindungi setiap satuan pendidikan atas pengaruh negatif Covid-19. Sesuai dengan pedoman penyelenggaraan, hal ini akan berguna untuk menanggulangi Tersebarnya dan menularkan Covid-19 dalam satuan pendidikan seperti guru, siswa, dan staf lainnya dan memastikan terpenuhinya dukungan psikososial untuk guru, siswa dan orang tua. Surat edaran ini sudah diterbitkan dan disiarkan melalui televisi, radio, surat kabar, dan pastinya pihak sekolah sudah menerima surat edaran tersebut. Seperti yang dikemukakan oleh Pennington (2020:33), penutupan sekolah dapat menjadi langkah yang efektif untuk mencegah penyebaran virus, tetapi waktu dan penerapannya perlu diperhitungkan.

Pembelajaran sebelum pandemi dan saat pandemi sangatlah berbeda. Pembelajaran sebelum pandemi, guru dan siswa masih bisa bertatap muka secara langsung di sekolah, tetapi saat pandemi berlangsung guru dan siswa diharuskan melaksanakan pembelajaran dengan jarak jauh atau tanpa bertatap muka, di mana bertujuan dalam pencegahan tersebarnya Covid-19. Pembelajaran daring yang diterapkan juga masih baru dalam dunia pendidikan, guru dan murid harus bisa beradaptasi dengan pembelajaran daring ini. Menurut Oktafia dan Siti (2020:498), pembelajaran dalam jaringan ialah system belajar di mana terlaksanakan secara tanpa tatap muka, namun pelaksanaannya mempergunakan aplikasi yang bisa menolong dalam langkah pembelajaran yang dilaksanakan dalam jarak yang berjauhan. Banyak aplikasi yang dapat digunakan seperti Edmodo, Scoology, Google Classroom dan lain-lain yang bisa dipergunakan dalam untuk peserta didik maupun pendidik pada upaya menunjang lancarnya proses belajar dan mengajar.

Pembelajaran sebagai suatu pedoman dalam standar proses yang disesuaikan dengan kurikulum 2013 yang ditetapkan pada aturan menteri pendidikan dan kebudayaan Republik Indonesia atau biasa dikenal melalui sebutan Permendikbud RI nomor 65 tahun 2013 berkaitan dengan langkah yang mencakup tahapan merencanakan belajar, melaksanakan langkah belajar-mengajar, menilai hasil dan langkah dalam belajar, dan juga mengawasi dalam belajar. Pengajar akan membuat perencanaan pembelajaran sebelum pembelajaran berlangsung sehingga guru akan mudah dalam mengajar siswa. Perencanaan yang dibuat bisa berupa RPP, silabus, materi pelajaran dan sebagainya. Hanya saja guru harus menyusun strategi sehingga tidak hanya fokus terhadap pemberian materi saja, tetapi juga melaksanakan kewajibannya untuk mendidik pebelajar agar memiliki budi pekerti, karakter, dan kepribadian yang luhur (Kadek Wirahyuni, 2017:17). Guru aktif menerangkan, tetapi harus dibarengi dengan siswa mendengarkan materi dengan saksama. Jika hanya guru memberikan penjelasan dan peserta didik diperlukan untuk mendengar materi yang diberikan tujuan belajar mengajar tidak akan tercapai. Sementara keberhasilan pembelajaran tak luput dari peran aktif peserta didik dalam proses belajar , tetapi jika siswa hanya mendengarkan bahan yang diajarkan tujuan pembelajaran tidak akan tercapai (Mas Dewantara, 2012:4).

Dari pengamatan yang dilakukan, secara umum terdapat kendala yang dialami sekolah Pada pelaksanaan kegiatan pembelajaran secara online di masa pandemi Covid-19. Salah satu sekolah yang ditunjang dengan fasilitas, SDM, dan daya dukung kemampuan ekonomi orang tua tetap tak menutup kemungkinan munculnya kendala dalam pembelajaran. Sekolah di Buleleng rata-rata memfasilitasi siswa dalam melaksanakan pembelajaran daring seperti membagikan paket data gratis kepada siswa tiap bulannya. Walaupun paket data telah diberikan oleh pihak sekolah, hal tersebut tidak menutup kemungkinan munculnya kendala salah satunya kendala sinyal. Tidak hanya siswa, guru pun juga difasilitasi oleh sekolah dengan pembagian paket data yang telah dilakukan ketika pembelajaran daring diterapkan. Di sekolah juga sudah tersedia jaringan nirkabel dan juga komputer sekolah yang dapat digunakan oleh guru. Guru dan juga staff lainnya juga sudah bergulat dalam dunia teknologi meskipun ada beberapa guru yang masih gaptek. Guru yang gaptek dapat dikatakan bisa menggunakan gawai dan laptop hanya saja penggunaan media yang dipakai dalam kelas dapat dikatakan ketinggalan zaman. Tetapi hal tersebut tidak menutup kemungkinan guru akan belajar berteknologi dalam pembelajaran 


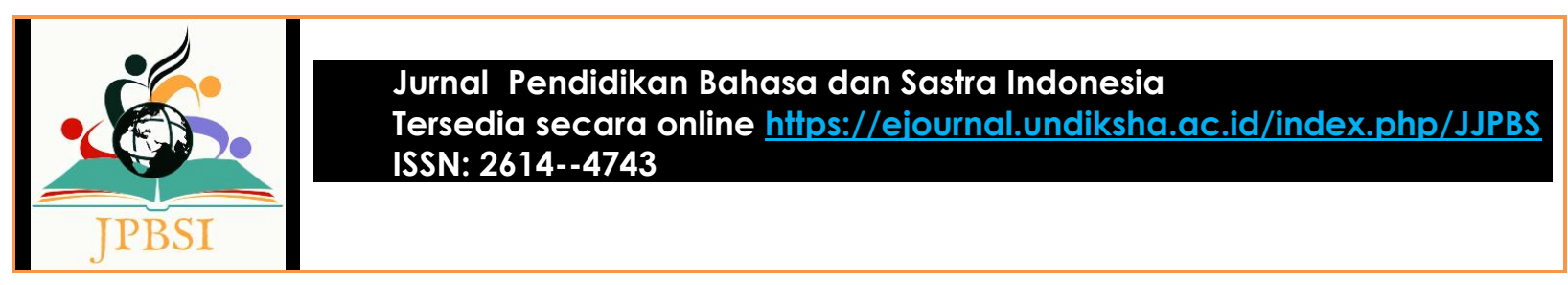

bersama guru yang lainnya. Daya dukung orang tua dalam pembelajaran juga sangat berperan penting dalam menunjang pembelajaran, setiap siswa rata-rata memiliki gawai dan laptop yang dapat digunakan dalam pembelajaran. Hanya saja terkadang gawai dan laptop yang digunakan bermasalah ketika dipakai saat Google Classroom, Google Meet dan aplikasi belajar yang lain. Dari pengamatan itu penunjang pembelajaran sudah mendukung hanya masih saja terdapat kendala yang bermunculan ketika pembelajaran daring. Salah satu sekolah di Buleleng yang keadaannya serupa adalah SMP Lab Undiksha.

Berlandaskan penguraian tersebut, pembelajaran Bahasa Indonesia pada masa pandemi sebagaimana yang dilakukan di SMP Lab Undiksha perlu untuk dikaji. Kajian ini penting untuk memberikan gambaran terkait kendala dan upaya yang dilakukan guru terkait perencanaan, pelaksanaan, dan respons siswa terhadap pembelajaran daring yang diterapkan di SMP Lab Undiksha Singaraja.

\section{METODE PENELITIAN}

Babbie, E. (dalam Etta dan Sopiah, 2010:4) mengemukakan "metode penelitian umumnya sebagai langkah ilmiah dalam mendapatkan data melalui sasaran dan ketergunaan yang telah ditentukan". Bagian metode penelitian berguna untuk membantu peneliti dengan menguraikan langkahlangkah dalam penelitian, terdapat varian metode penelitian ialah wawancara dengan mewawancarai guru Bahasa Indonesia untuk mengumpulkan data, observasi ke kelas dengan metode daring yang digunakan, pendokumentasian berupa mengumpulkan data-data lengkap, angket dengan memberikan beberapa pertanyaan dengan menggunakan aplikasi google form yang memudahkan siswa mengakses.

Jenis rancangan studi yang dipergunakan ialah penelitian deskriptif kualitatif. Sugiyono (dalam Suandi, 2008) mengemukakan "dalam penelitian bukan dimaksudkan untuk mengujikan hipotesis, tetapi hanya memberikan deskripsi keterangan yang nyata". Rancangan studi yang dipergunakan adalah rancangan studi deskriptif kualitatif yang digunakan untuk mendeskripsikan data dari pemahaman terkait pembelajaran Bahasa Indonesia di masa wabah Covid-19 di SMP Lab Undiksha Singaraja dengan data yang diperoleh dari guru Bahasa Indonesia SMP Lab Undiksha Singaraja.

Wendra (2019:124) mengemukakan "subjek penelitian ialah individu yang dituju oleh sebuah aksi di mana subjek pada studi ini ialah peserta didik kelas XI-1 dan guru Bahasa Indonesia". Alasan peneliti memilih di kelas tersebut dikarenakan kelas tersebut lebih komunikatif dibandingkan kelas yang lainnya. Selain itu, pemilihan SMP Lab Undiksha selaku lokasi penelitian disebabkan sekolah ini sebagai sekolah favorit dan juga sekolah tersebut merupakan sekolah yang difasilitasi lengkap tetapi tetap muncul kendala. Penelitian yang peneliti laksanakan ini mencakup jenis analisis induktif melalui penggunaan data yang memiliki sifat kualitatif dengan begitu langkah analisis induktif bisa mencari penarikan kesimpulan melalui pengumpulan di mana arah tendensi pada umumnya. Metode penganalisisan data induktif yang terdapat pada studi ini yakni peneliti mengamati pembelajaran Bahasa Indonesia pada masa pandemi Covid-19 di SMP Lab Undiksha tidaklah berbeda jauh dengan pembelajaran Bahasa Indonesia sebelum pandemi Covid-19. Hal ini diperkuat dengan pemaparan guru terkait perencanaan pembelajaran yang disiapkan sebelumnya sebelum pembelajaran berlangsung seperti media pembelajaran seperti salindia atau video pembelajaran, LKPD, materi pembelajaran, RPP, Silabus, dan sebagainya. Hal yang membedakan hanyalah jam pembelajaran yang biasanya 6 jam dalam seminggu tetapi setelah pandemi Covid-19 jam pembelajaran hanya 2 jam dan juga pembelajaran jarak jauh membuat guru dan siswa terkadang sulit untuk bisa berkomunikasi secara lancar karena terkendala sinyal. 


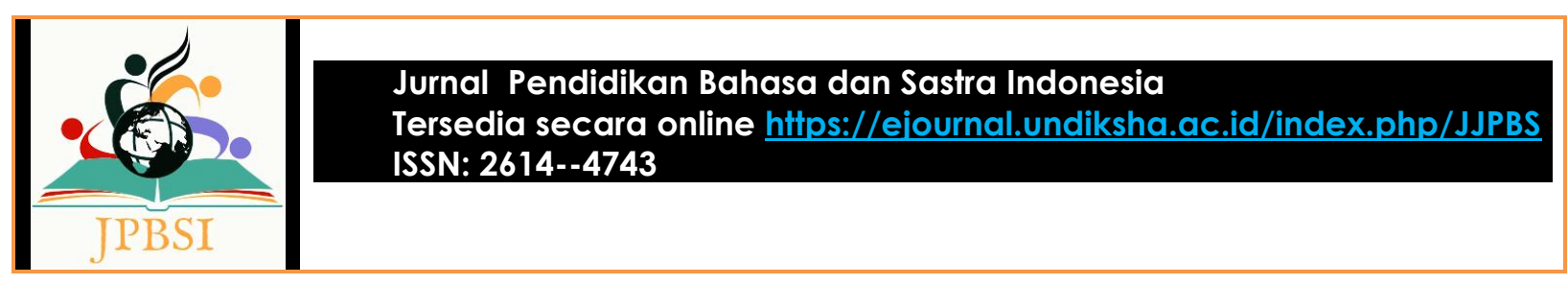

\section{HASIL DAN PEMBAHASAN}

\section{Perencanaan Pembelajaran Bahasa Indonesia pada Masa Pandemi Covid-19 di SMP Lab Undiksha.}

Dalam pembelajaran setiap guru mempersiapkan bahan-bahan penunjang pembelajaran. Contohnya dalam wawancara yang dilakukan dengan guru Bahasa Indonesia SMP Lab Undiksha yakni guru Bahasa Indonesia. Berikut ini hasil wawancara terhadap .

Pertanyaan : Apa perencanaan yang ibu siapkan sebelum pembelajaran Bahasa Indonesia di kelas IX-1?

Jawaban : Perencanaan pembelajaran yang ibu siapkan sebelum pembelajaran di kelas berlangsung yang pertama adalah silabus. Silabus mencakup semua materi dalam kelas yang dibuat saat awal semester. Untuk pembelajaran setiap pertemuan guru membuat RPP terbaru yang biasanya banyak halaman yang digunakan. Nah untk saat ini guru hanya membuat RPP satu lembarnya menggunakan metode daring seperti Google Classroom, Google Meet, Zoom Meeting dengan pembuatan video dan membuatkan anak-anak LKPD materinya ada dalam bentuk video dan juga power point agar bisa mengetahui atau mengukur pemahamannya lebih lanjut menggunakan LKPD yaitu dengan menugaskan anak-anak didalam membuat latihan yang tedapat dalam buku paket. Pelaksanaannya kalau misalnya siswa mengerjakan tugas-tugas terdapat masalah dan juga kendala bisa bertanya melalui Whatsaapp grup itu biasanya yang sudah sering dilaksanakan di kelas. Jadi kalau di perencanaan, terdapat RPP terbaru yaitu dengan pembuatannya 1 lembar kertas, menyiapkan anak-anak materi melalui power point, membuatkan LKPD sebagai latihan-latihan siswa dalam rangka pendalaman materi yang dilihat dalam menjawab LKPD, video pembelajaran. Nah dalam perencanaan juga guru membuatkan skorskor penilaian, membuatkan grup kelas melalui aplikasi Google Classroom.

Dalam penjelasan yang disampaikan oleh guru Bahasa Indonesia yakni guru Bahasa Indonesia bahwasanya dalam perencanaan pembelajaran adapun beberapa yang perlu dipersiapkan seperti Silabus, RPP, LKPD dan juga video pembelajaran yang digunakan sebagai materi yang dibagikan kepada siswa. Adapun silabus yang digunakan berisikan pengenalan sekolah, komponen isi, kompetensi dasar, bahan ajar pokok, nilai karakter, kegiatan belajar mengajar, pengevaluasian, banyaknya waktu, sumber data. Dalam menyusun silabus sudah benar hanya saja ada beberapa yang tidak sesuai antara yang tercantum dalam silabus dengan pengamatan yang peneliti temukan. Contohnya saja yang peneliti temukan penggunaan sumber belajar dalam silabus tercantum buku paket, buku penunjangterbitan yudistira, buku penunjang terbitan yrama widya, buku ringkasan materi, sedangkan yang sumber yang dipergunakan pendidik ialah buku paket dan juga internet yang digunakan untuk mencari video pembelajaran dan juga materi lainnya. Tidak hanya silabus, ada pula RPP yang digunakan pada tahap perencanaan pembelajaran. Sesuai surat edaran yang diterbitkan oleh Kemendikbud, RPP yang awalnya dibuat dengan halaman yang banyak kini hanya dibuat dalam 1 halaman saja. Hal ini mempermudah guru dalam membuat RPP dan mempersingkat waktu dalam menyiapkan bahan-bahan sebelum pembelajaran dimulai. Dalam RPP tercantum beberapa komponen seperti identitas sekolah, tujuan pembelajaran, langkah-langkah pembelajaran dan penilaian.

Dalam penyusunan LKPD, LKPD dibuat berdasarkan materi yang telah dibagikan oleh guru melalui aplikasi Google Classroom dan juga materi yang telah dipelajari bersama oleh siswa dan guru melalui pertemuan daring menggunakan aplikasi Google Meet. LKPD dibuat dalam pengukuran kesanggupan peserta didik ketika paham terkait bahan ajar yang telah dipelajari bersama. Terakhir yaitu video pembelajaran dan juga salindia, video pembelajaran dan salindia dibuat dengan menggunakan sumber buku paket dan juga internet. Buku paket sudah dimiliki oleh seluruh siswa jadi siswa yang sudah belajar pastinya akan mengetahui pelajaran yang selanjutnya akan dibahas sehingga dalam pertemuan menggunakan aplikasi Google Meet guru akan mengulasnya kembali dan juga memperkuat 


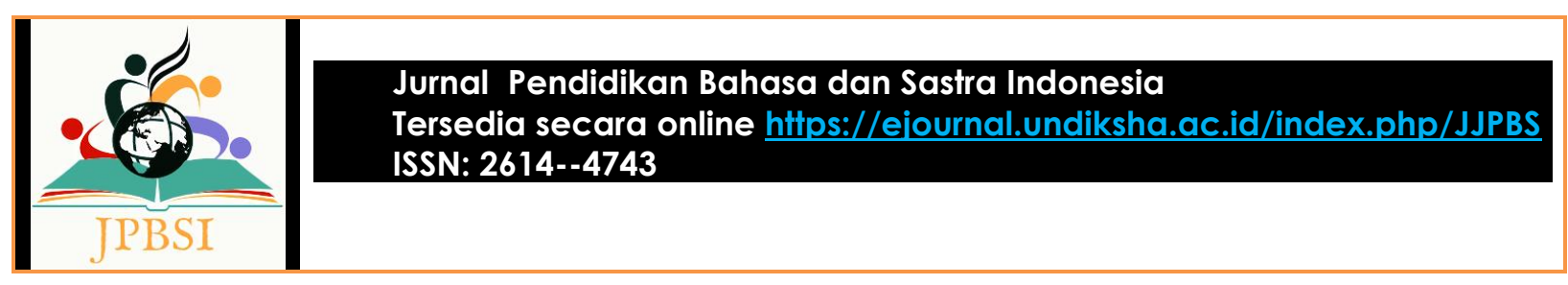

wawasan siswa. Video pembelajaran dan juga salindia dibuat dengan singkat dan juga jelas, dalam menampilkan video pembelajaran dan juga salindia dibarengi dengan pemaparan guru sehingga siswa mudah mengerti terhadap media yang ditampilkan.

Sesuai dengan data dilapangan, dalam penyususnan RPP pembelajaran Bahasa Indonesia, Guru memiliki pedoman dalam Silabus dan disesuaikan melalui buku paket yang dipergunakan. Maka dari itu guru dapat mengetahui terkait dengan bahan ajar yang tertera pada silabus yang termuat pada buku paket yang dipergunakan. Dalam penelitian ini, penulis melakukan wawancara pada guru Bahasa Indonesia terkait perencanaan pembelajaran Bahasa Indonesia di masa pandemi Covid-19 di SMP Lab Undiksha Singaraja yang diuraikan sebagai berikut.

"Perencanaan pembelajaran yang ibu siapkan sebelum pembelajaran di kelas berlangsung yang pertama adalah silabus. Silabus mencakup semua materi dalam kelas yang dibuat saat awal semester."

Silabus yang guru gunakan pada masa pembelajaran pandemi Covid-19 tidaklah berbeda dari silabus yang digunakan sebelum pandemi Covid-19. Yang terpenting setiap Silabus memberi arahan berkaitan dengan hal apa yang seharusnya diwujudkan guna tercapainya sebuah tujuan dalam belajar dan pembelajaran dengan langkah selayaknya berkaitan dengan hal yang akan dipergunakan (Gunawan, 2020:48). Dari kedua silabus tersebut juga sudah menggapai tujuan pembelajaran, walaupun metode yang digunakan berbeda tetapi tujuan yang ingin dicapai itu sama.

"Untuk pembelajaran setiap pertemuan guru membuat RPP terbaru yang biasanya banyak halaman yang digunakan. Nah untuk saat ini guru hanya membuat RPP satu lembarnya menggunakan metode daring seperti Google Classroom, Google Meet, Zoom Meeting dengan pembuatan video dan membuatkan anak-anak LKPD materinya ada dalam bentuk video dan juga power point agar bisa mengetahui atau mengukur pemahamannya lebih lanjut menggunakan LKPD yaitu dengan menugaskan anak-anak agar membuat latihan yang terdapat dalam buku paket.”

RPP sangatlah penting dalam sebuah pembelajaran dengan melihat pentingnya penyusunan. Tidak berbeda halnya dengan RPP yang digunakan dalam pembelajaran, RPP pada umumnya berisikan identitas sekolah, skenario, media pembelajaran, dan lain sebagainya. RPP yang digunakan saat pandemi dan setelah pandemi pun tidak ada bedanya hanya saja perbedaan yang sangat tampak yaitu pada media pembelajaran yang digunakan karena pada masa pandemi siswa dan guru melaksanakan pembelajaran metode daring dengan menggunakan berbagai aplikasi belajar yang bisa mempermudah pendidik dan peserta didik dalam berinteraksi dengan lancar. Aplikasi belajar yang digunakan oleh guru yaitu Google Classroom, Google Meet, dan aplikasi lainnya.

"Pelaksanaannya siswa mengerjakan tugas-tugas jika terdapat masalah dan juga kendala bisa bertanya melalui Whatsaapp grup itu biasanya yang sudah sering dilaksanakan di kelas. Jadi kalau di perencanaan, terdapat RPP terbaru yaitu dengan pembuatannya 1 lembar kertas, menyiapkan anak-anak materi melalui power point, membuatkan LKPD sebagai latihan-latihan siswa dalam rangka pendalaman materi yang dilihat dalam menjawab LKPD, video pembelajaran. Nah dalam perencanaan juga guru membuatkan skor-skor penilaian, membuatkan grup kelas melalui aplikasi Google Classroom."

LKPD juga tidak jauh berbeda antara sebelum pandemi dan saat pandemi, hanya saja ketika pandemi LKPD dan juga video pembelajaran dibagikan secara online melalui Google Classroom setelah pembelajaran melalui Google Meet selesai. Video pembelajaran juga dapat ditampilkan melaui aplikasi Google Meet yang dapat disaksikan oleh seluruh siswa.

Penelitian serupa juga dilakukan oleh Riwan (2014) bahwa dalam kajiannya peneliti meneliti mengenai perencanaan pembelajaran Bahasa Indonesia pada sekolah tersebut. Dalam tahapan merencanakan proses belajar memngajar, guru bahasa Indonesia kelas VII SMP Negeri 2 Amlapura 


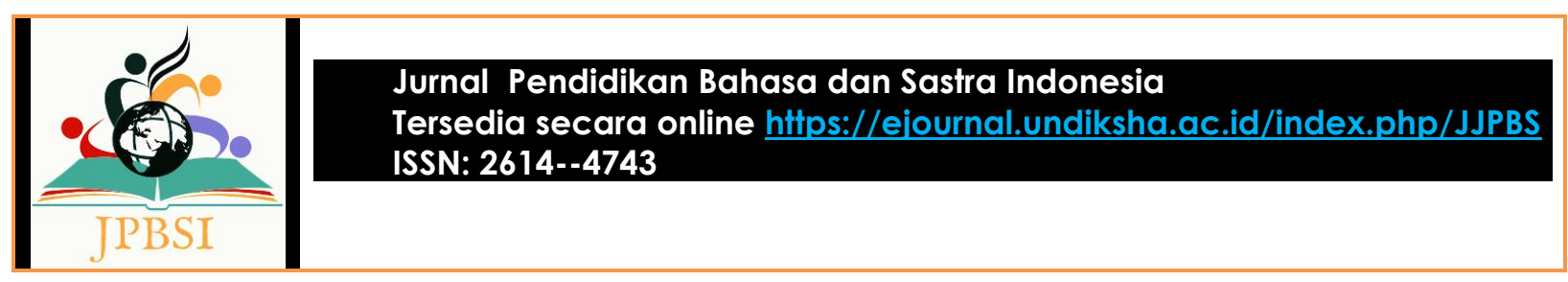

mempergunakan silabus yang sudah diperkembangkan dari Kementerian Pendidikan dan Kebudayaan (Kemdikbud) selaku acuan menyususn perencanaan terlaksananya pembelajaran. Dan dalam perencanaan di SMP Lab Undiksha guru juga menggunakan silabus dan juga RPP yang digunkan sebagai rancangan didalam proses belajar mengajar. Hanya saja penelitian yang dilakukan oleh Riwan dilaksanakan sebelum pandemi Covid-19 dan siswa yang diajarkan tidak menggunakan sistem daring sehingga guru tidak menggunakan aplikasi pendukung seperti Google Meet, Google Classroom, Google Form dan sebagainya. Dan juga guru menerangkan materi masih dibantu oleh papan tulis dikelas sehingga tidak menggunakan salindia seperti yang dilaksanakan di SMP Lab Undiksha di masa pandemi Covid-19 semacam saat ini. Sehingga penelitian yang dilakukan oleh Riwan tidak memakan waktu banyak dalam perencaan seperti yang dilakukan guru SMP Lab Undiksha yang perlu menyiapkan link absen, link Google Meet, Salindia, dan juga video pembelajaran.

Temuan penelitian ini terkait langkah guru menyiapkan pembelajaran sejalan dengan pendapat Hamzah (2010:3), bahwa pembelajaran yang nantinya terencanakan membutuhkan beberapa kajian dalam proses perancangan supaya perencanaan belajar mengajar yang tengan disusunya bisa mencukupi apa yang menjadi sasaran belajar mengajar. Selain itu, juga dibuat dengan pemikiran yang matang sehingga pembelajaran bisa berlangsung dengan sesuai sasaran didalam pembelajaran. Temuan penelitian ini terkait langkah guru menyiapkan pembelajaran sejalan dengan pendapat Wina (2008:23) bahwa rencana pembelajaran sebagai perolehan atas langkah pemikiran, diartikan yakni tersusun dengan tidak semata-mata hanya menyusun namun dengan pertimbangan seluruh bagian yang memungkinkan bisa berdampak, disamping tersusun melalui pertimbangan seluruh sumber daya yang disediakan yang bisa menjadi pendukung pada kesuksesan langkah pembelajaran.

Guru membuat rancangan pembelajaran haruslah berpedoman pada Peraturan Pemerintah RI No. 19 Tahun 2005 berkaitan Standar Nasional Pendidikan pasal 20, yakni menyatakan perencanaan langkah mengajar mencakup silabus dan RPP. Sehingga minimal pendidik yang nantinya melangsugkan pembelajaran wajib menyiapkan RPP dan juga silabus sebelum pembelajaran di mulai. Rancangan pembelajaran dibuat guru dalam kurun waktu yang singkat mengingat pembelajaran pada pertemuan pertama dan kedua hanya berjarak 3 hari hingga 1 minggu. Sesuai dengan pendapat Mela (2012:8) bahwasanya rencana belajar pendidik lebih dulu disiapkan RPP atas aktivitas sehari sebelum dilaksanakannya proses belajar mengajar yang tersusun berlandaskan rancangan aktivias mingguan yang sudah tersusu dari perserikatan pendidik.

\section{Pelaksanaan Pembelajaran Bahasa Indonesia pada Masa Pandemi Covid-19 di SMP Lab Undiksha}

Data yang diperoleh saat observasi pertama di kelas IX-1, dengan KD 3.11 mengidentifikasikan bagian isi pengungkapan empati, peduli, simpati maupun rasa individu dari teks bacaan yang menginspirasi yang dibacakan dan didengarkan dan KD 4.11 memberikan simpulan atas isi pengungkapan rasa empati, simpati, peduli maupun rasa individu pada wujud penceritaan inspiratif yang dibacakan dan didengarkan. Kompetensi dasar tersebut dapat terdeskripsikan berdasar aktivitas diawal, inti, dan diakhir.

Dalam aktivitas awal pendidik membagikan tautan Google Meet kepada siswa melalui media sosial whatsapp grup. Setelah siswa bergabung dalam Google Meet tersebut guru akan diawali pembelajaran melalui pemberian salam dilanjutkan dengan menanyakan kabar dan juga mengingatkan siswa untuk tetap menjaga kesehatan. Guru juga menyarankan siswa untuk menghidupkan kamera yang ada di layar laptop atau hp siswa agar guru bisa melihat keadaan siswa secara langsung. Pembelajaran daring tidak akan membuat guru dan siswa terputus komunkasi, karena teknologi yang semakin pesat. Setelah itu guru akan bertanya ke ketua kelas berkaitan absen peserta tidik yang tidak masuk, tidak hanya itu guru juga akan mengirimkan tautan absen Google Form yang akan dibagikan melalui obrolan dalam Google Meet. Sebelum memulai pembelajaran guru akan menginstruksikan seorang siswa agar 


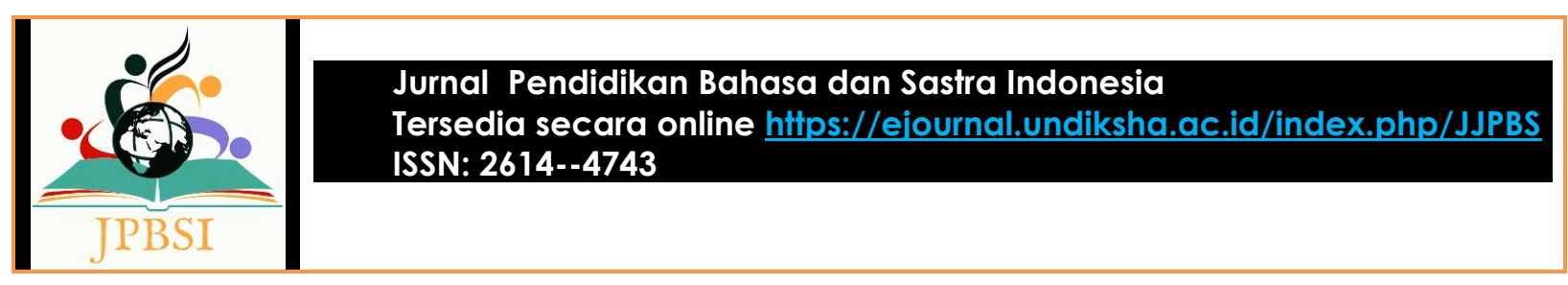

memimpin doa menurut agama dan kepercayaan tiap-tiap siswa. Doa akan dipimpin oleh salah satu siswa melalui menundukkan kepala sejenak yang memiliki tujuan agar memohonkan kelancaran ketika melaksanakan aktivitas pembelajaran. Kemudian, pembelajaran dimulai, pendidik memberikan apersepsi, bertanya kepada siswa untuk mengawali pembelajaran biasanya guru akan bertanya terkait pembelajaran minggu lalu sehingga hal ini berguna dalam melatih daya ingat peserta diidk pada bahan ajar yang sudah dilalui sebelum-sebelumnya.

Apersepsi merupakan pertanyaan yang akan membantu siswa dalam mengasah pengetahuannya sebelum proses pembelajaran dimulai. Pertanyaan itu berupa "Apakah anak-anak masih ingat apa yang kita pelajari minggu lalu?" dan siswa menjawab "Saya bu", sesudah satu siswa memberikan jawaban atas apa yang ditanyakan pendidik dan jawaban kurang tepat guru nantinya memberi peluang untuk peserta didik lainnya agar mencoba menjawabkan pertanyaan yang ditanya oleh pendidik. Seluruh siswa berusaha mendapatkan kesempatan agar bisa menjawab pertanyaan dari guru. Banyak peserta didik yang ingin memebrikan jawaban pertanyaan dikarenakan peserta didik yang dapat menjawab pertanyaan akan diberikan nilai tambahan oleh guru sehingga keaktifan siswa dikelas akan meningkat. Nilai tambahan yang diberikan membuat siswa lebih aktif di kelas yang bisa diperhatikan dari siswa yang jarang aktif didalam kelas akan terpacu sehingga akan bersaing dengan siswa yang aktif sebelumnya. Setelah terdapat siswa yang mecoba memberi jawaban atas apa yang ditanyakan guru secara benar, guru akan memberikan nilai tambahan dalam tabel yang sudah disediakan.

Pada awal pembelajaran guru tidak langsung memberi penyampaian bahan ajar yang perlu untuk dipelajari di hari tersebut. Pendidik memberi beberapa pertanyaan lagi yang berhubungan pada bahan ajar contohnya "Apakah terdapat anak yang sudah mendengarkan cerita inspiratif?" lalu setelah ada anak yang menjawab dilanjutkan dengan pertanyaan "Apakah ada yang tau pengertian cerita inspiratif?". Sebelum guru memaparkan materi guru akan menampilkan sebuah salindia yang digunakan guru sebagai media dalam pembelajaran. Guru juga menampilkan sebuah video pembelajaran yang ditampilkan di Google Meet. Biasanya yang terdapat salindia adalah poin-poin dalam materi yang nantinya akan disampaikan secara lengkap oleh guru menggunakan salindia tersebut. Pemaparan dalam salindia harus singkat dan jelas, salindia dibuat dengan pemaparan yang singkat dengan tujuan supaya peserta didik tidak kebingungan jika guru memberikan penyampaian supaya peserta didik mampu mencermati dengan baik terkait yang dipaparkan oleh guru. Siswa akan dilatih dalam memahami materi dengen mendengar penjelasan guru. Bagi siswa yang mendengarkan secara teliti akan mampu memahami seluruh materi, tetapi bagi siswa yang tidak memahami materi dengan baik pasti akan kebingungan jika ditanya guru karena pemahaman terhadap materi yang sedikit ditangkap.

Sebelum guru memaparkan lebih jauh, siswa diharapkan mampu mengetahui dan mencermati bagian dari cerita inspiratif itu sendiri, seperti pengertian, ciri-ciri, jenis. Siswa terlebih dahulu diasah pengetahuannya tentang pengertian, ciri-ciri, jenis pembentuk cerita inspiratif, barulah guru menjelaskan lebih lanjut materinya

Setelah beberapa menit keadaan siswa hening, guru langsung bertindak merasakan hal tersebut, dengan bertanya "Kalau ada yang belum paham, atau masih bingung tanyakan saja ke ibu! Ada yang ingin bertanya?" Tidak lama ada siswa yang mengangkat tangannya dan bertanya "Bu, apa yang membedakan cerita inspiratif dengan cerita lainnya?", "ya pertanyaan yang bagus! Ada yang tau perbedaan cerita inspiratif dengan cerita lainnya?" guru mengembalikan pertanyaan siswanya ke siswa yang lain. Hal ini berguna agar semua siswa dapat berbicara di dalam kelas dan mengutarakan pendapatnya. Namun, siswa hanya diam tanpa menghidupkan kamera maupun tombol suara. Hal ini terjadi beberapa menit saja, karena guru langsung menjelaskan ke semua siswa berdasarkan pertanyaan yang diajukan oleh siswanya. Sehingga siswa kembali memerhatikan guru yang sedang menjelaskan. Setelah itu guru memberikan pertanyaan ke siswa terkait pengertian, ciri-ciri, dan jenis-jenis yang digunakan dalam menjelaskan cerita inspiratif. 


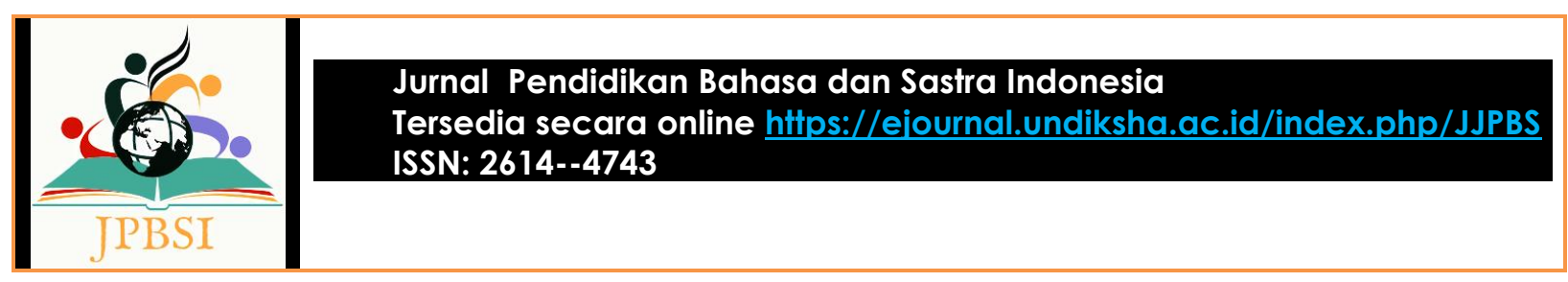

Setelah siswa mengetahui dan mengerti mengenai pengertian, ciri-ciri, dan jenis pada cerita inspiratif, dengan bantuan salin dia dan buku paket yang digunakan guru maupun siswa sebagai pedoman. Selanjutnya guru mempersilahkan bagi siswa yang ingin bertanya, jika terdapat peserta didik bertanya guru akan membuat penjelasan hingga peserta didik itu paham. Sebagai umpan balik dalam pembelajaran ini guru mengajukan beberapa pertanya sebagai alat ukur pemahaman siswa.

Selanjutnya guru membagikan tugas melalui Google Classroom yang digunakan guru dan siswa dalam mengirim dan mengumpulkan tugas. Tugas biasanya dikumpulkan dalam kurun waktu 2 hari. Hal itu bertujuan supaya peserta didik bisa mengerjakan tugas dengan santai tanpa adanya rasa terbebani. Sesudah guru menjelaskan mengenai tugas. Guru langsung menutup pembelajaran dengan doa sesudah itu pendidik memberikan instruksi silahka untuk peserta didik agar meninggalkan Google Meet dan memulai membuat tugas yang sudah diberi dengan baik.

Data yang diperoleh saat observasi kedua kelas IX-1 dengan KD 3.12 melakukan penelaah struktur, bahasa, dan isian dari teks cerita inspiratif dan KD 4.12 memberi ungkapan empati, simpati, , peduli, dan rasa didalam wujud cerita inspiratif melalui melihat struktur cerita dan bagian bahasa. Observasi pertama juga kedua skenario pembelajarannya hampir tidak bisa dibedakan hanya saja dalam pengamatan ke-2 pendidik melanjutkan materi yang sudah diajarkan sebelumnya. Dari data yang telah dikumpulkan, peneliti meninjau pembelajaran sebelum pandemi dan saat pandemi Covid-19 tidak jauh berbeda dalam segi berlangsungnya pembelajaran, hanya saja yang berbeda proses pembelajaran sata pandemi dilaksanakan dengan daring dan kendala juga sering bermunculan ketika pembelajaran berlangsung.

Temuan penelitian ini terkait langkah guru menyiapkan pembelajaran sejalan dengan pendapat Mega (2020) bahwa dalam pelaksanaan pembelajaran daring, guru dapat membuat media pembelajaran yang memudahkan siswa memahami materi yang disampaikan oleh guru, misalnya video animasi, power point, mind map, atau video penjelasan langsung dari guru. Kedua melakukan pembelajaran tatap muka satu minggu satu kali. Di era seperti ini guru dituntut untuk lebih kreatif, terlebih dalam menggunakan media, metode, atau strategi pembelajaran. Adanya pandemi Covid-19 ini pemerintah menganjurkan untuk mengalihkan pembelajaran konvensional menjadi daring, namun ada baiknya jika pembelajaran daring ini dibarengi dengan melakukan pembelajaran satu kali dalam satu minggu dengan memperhatikan beberapa hal diantaranya, wilayah sekolah merupakan zona aman atau zona hijau, tetap mematuhi protokol kesehatan, dan benar-benar mendapatkan ijin dari berbagai pihak. Dengan melakukan pembelajaran tatap muka satu kali selama satu minggu dapat dimanfaatkan oleh guru untuk mengevaluasi siswa, agar guru mengetahui perkembangan siswa selama melakukan pembelajaran daring.

Pembelajaran Bahasa Indonesia di sekolah mulai dilaksanakan secara daring sejak beredarnya surat edaran mengenai kebijakan sekolah saat pandemi yang diluncurkan oleh Menteri Pendidikan dan Budaya pun memberikan ketentuan, yakni proses pembelajaran dilaksanakan dari rumah untuk memberikan pembelajaran yang bermakna melalui pembelajaran daring atau jarak jauh (Mendikbud, 2020). Pelaksanaan pembelajaran daring mengharuskan guru dan siswa melaksanakan proses belajar mengajar dari rumah. Tetapi pelaksanaan pembelajaran daring yang sudah berjalan dirasa belum optimal dalam penyampaian materi pembelajaran kepada murid, karena biasa belajar di kelas secara face-to-face, sekarang penyampaian materi melalui sebuah wadah (Arifah dan Iis, 2021:636). Pelaksanaan pembelajaran secara daring akan terlihat teacher centered atau lebih dikenal dengan pembelajaran yang berpusat pada guru karena pembelajaran berjalan dengan jarak jauh yang dibatasi oleh layar kaca HP dan juga laptop. Dalam hal ini diketahui bahwasannya pembelajaran daring yang sudah terlaksana sejak pertengahan bulan Maret tahun 2020 membuktikan pembelajaran daring yang terlaksana memiliki banyak kekurangan dan juga kendala dari pihak siswa maupun pihak guru. 


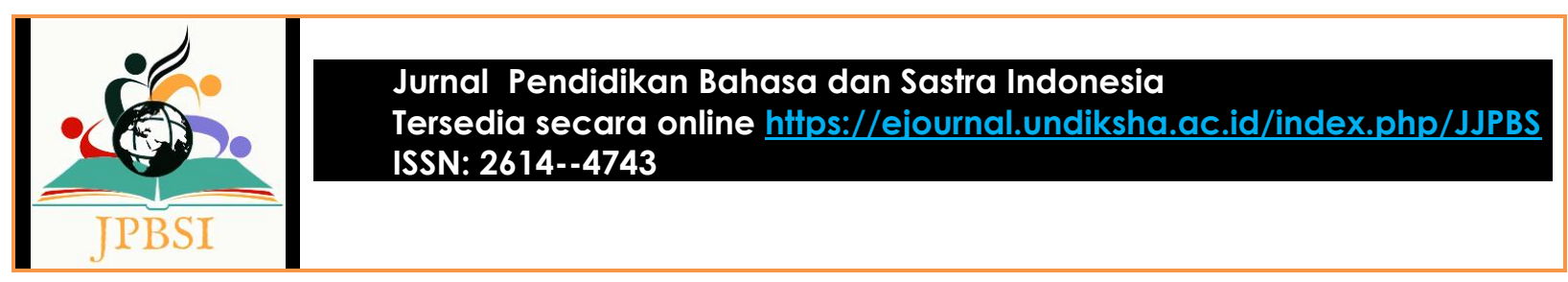

\section{Respons Siswa Terhadap Pembelajaran Bahasa Indonesia pada Masa Pandemi Covid-19 di SMP Lab Undiksha}

Dalam sebuah pembelajaran perlu adanya peningkatan agar pembelajaran menjadi semakin baik. Pembelajaran dapat ditingkatkan melalui respons siswa. Menurut pusat bahasa (dalam Wahyu Widhiarso, 2012:119) dijelaskan bahwa respons adalah tanggapan, reaksi, atau jawaban individu. Dalam penelitian ini respons siswa digali menggunakan aplikasi Google Form. Hal ini dikarenakan pandemi yang melanda Indonesia dan merubah sistem pendidikan yang awalnya tatap muka beralih menjadi daring atau dalam jaringan. Sistem daring mengharuskan siswa dan guru belajar dari rumah sesuai dengan arahan Kemendikbud.

Aplikasi Google Form mempermudah peneliti dalam mengumpulkan data berupa respons siswa. Respons siswa digali dengan beberapa pertanyaan yang diajukan oleh peneliti terkait pembelajaran Bahasa Indonesia pada masa pandemi Covid-19.

Respons siswa sangat penting dalam sebuah penelitian, dari respons siswa peneliti akan mengetahui apa saja kendala dan pendapat peserta didik didalam melaksanakan belajar bahasa Indonesia di masa wabah Covid-19. Pengumpulan respons sejumlah 21 siswa tidak dapat dilakukan dengan luring seperti membagikan angket berupa teks kepada siswa mengingat sekarang ini wabah Covid-19 tetap berlangsung di Indonesia. Maka dari itu pengumpulan respons siswa dilakukan menggunakan an dengan bantuan aplikasi Google Form. Google Form merupakan aplikasi yang sangat mudah digunakan baik siswa dan juga peneliti dan penggunaannya tidak dipungut biaya, sehingga peneliti memilih aplikasi ini dalam mengumpulkan respons siswa pada proses belajar Bahasa Indonesia pada masa Pandemi Covid-19.

Data respons siswa terhadap pertanyaan menunjukkan bahwasanya peserta didik lebih tertarik pada pembelajaran sebelum pandemi Covid-19 karena siswa merasakan sendiri ketika bersama temanteman akan jauh lebih menyenangkan dibandingkan dengan pembelajaran daring seperti yang diterapkan sekarang. Pembelajaran sebelum pandemi dilakukan dengan tatap muka antara siswa dan guru sehingga materi dengan mudah diserap oleh siswa.

Hasil angket mengenai pertanyaan nomor 1 setelah diakumulasi menunjukkan bahwa mayoritas siswa mengatakan pembelajaran secara tatap muka membuat siswa merasa senang, semangat dan tanpa kendala. Selanjutnya data respons siswa terhadap pertanyaan terkait belajar Bahasa Indonesia di masa wabah ini menunjukkan peserta didik belajar yang awal mulanya menyenangkan menjadi tidak menyenangkan dengan pembelajaran secara daring, hal ini dikarenakan interaksi diantara guru dan siswa tidak dilakukan dengan bertatap muka sehingga siswa merasa hal ini tidak membuat siswa semangat dalam pembelajaran. Tidak hanya itu siswa juga merasa pembelajaran dengan sistem daring membuat peserta didik kurang dapat meresapi bahan ajar yang disampaikan secara baik sebab kendala sinyal, dan kendala lainnya yang menghambat pembelajaran siswa.

Hasil angket mengenai pertanyaan nomor 2 setelah diakumulasi menunjukkan bahwa mayoritas siswa mengatakan pembelajaran secara daring membuat siswa hilang semangat, merasa pembelajaran sudah tidak menyenangkan seperti sebelumnya, sisa juga kebanayakan kurang bisa menyerap materi yang tersampaikan oleh guru secara baik, dan kendala juga bermunculan ketika pembelajaran daring berlangsung.

Hasil angket mengenai pertanyaan nomor 3 setelah diakumulasi menunjukkan bahwa mayoritas siswa mengharapkan pandemi ini segera berakhir sehingga bisa memudahkan siswa bertemu bersama guru dan teman-teman. Interaksi guru dan siswa mudah terjalin ketika bertatap muka dan seluruh siswa mengharapkan hal tersebut. Dengan tatap muka siswa dan guru akan mudah dalam pembelajaran siswa juga akan mudah memahami materi dan guru juga dengan mudah memaparkan materi tanpa harus selalu membuat salindian dan juga video pembelajaran. Terakhir data respons siswa terhadap pertanyaan 


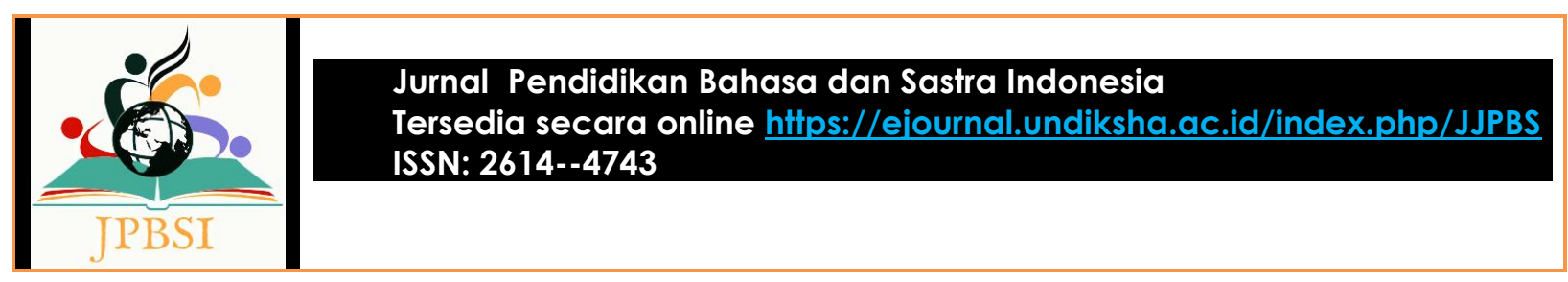

terkait harapan siswa kedepannya terhadap pembelajaran Bahasa Indonesia menunjukkan banyak siswa yang mengharapkan supaya pandemi Covid-19 kedepannya makin cepat berakhir agar nantinya pembelajaran bisa dilanjutkan dengan tatap muka, mengingat banyak siswa yang lebih menguasai materi dengan tatap muka. Interaksi guru dan siswa juga tidak dibatasi melalui layar kaca laptop maupun HP.

Temuan penelitian ini terkait langkah guru menyiapkan pembelajaran sejalan dengan pendapat Feri dan Rusdi (2020) bahwa rata-rata siswa memberikan respon yang baik terhadap materi yang diberikan secara online. Selanjutnya berkaitan hal tersebut, siswa diberikan pernyataan bersifat positif dan negatif masing-masing 8 poin terkait alasan mereka memilih jawaban senang/baik dan melakukan instruksi dari gurunya. Lebih dari $75 \%$ pernyataan positif dijawab setuju dari seluruh (106) siswa. Sedangkan lebih dari $50 \%$ pernyataan negatif memperoleh jawaban tidak setuju. Hal ini berkaitan dengan respons siswa di SMP Lab Undiksha, dari respons tersebut dapat simpulkan dari 21 siswa kelas XI-1. Pada pertanyaan nomor 1 siswa yang berpendapat mendukung terhadap pembelajaran sebelum pandemi sebanyak 19 siswa dan 2 siswa berpendapat tidak mendukung. Selanjutnya pada pertanyaan nomor 2 siswa yang berpendapat mendukung terhadap pembelajaran saat pandemi sebanyak 2 siswa dan 19 siswa berpendapat tidak mendukung. Terakhir pada pertanyaan nomor 3 siswa yang berpendapat positif terhadap harapan kedepannya mengenai pembelajaran Bahasa Indonesia sebanyak 21 siswa. Dari respons siswa yang telah dikumpulkan rata-rata siswa berpendapat bahwa pembelajaran pada masa pandemi Covid-19 memiliki kendala daripada pembelajaran sebelum pandemi Covid-19. Dalam pengumpulan angket peneliti menggunakan aplikasi Google Form yang dapat membantu peneliti mengumpulkan respons siswa. Respons siswa dapat sangat berpengaruh terhadap pembelajaran karena melalui respons siswa guru akan mampu mengembangkan cara mengajar sehingga dapat lebih sempurna. Hal ini sesuai dengan pendapat yang disampaikan oleh Sinta dan Imelda (2018) angket respons siswa adalah instrument yang digunakan untuk mengukur tanggapan siswa terhadap pembelajaran.

\section{PENUTUP}

Perencanaan pembelajaran Bahasa Indonesia pada masa pandemi Covid-19 di SMP Lab Undiksha Singaraja sudah mencakup komponen-komponen RPP 1 halaman yaitu identitas sekolah, kompetensi dasar, indicator, alokasi waktu, tujuan pembelajaran, materi pembelajaran, metode pembelajaran, langkah-langkah, sumber belajar, dan penilaian. Tidak hanya RPP ada pula perencaaan pembelajaran lainnya yang dibutuhkan guru sebelum memulai pembelajaran antara lain Silabus, Google Meet, Google Classroom, LKPD, Salindia, Video Pembelajaran, dan Absen Online. Selanjutnya pelaksanaan pembelajaran Bahasa Indonesia berdasarkan hasil observasi di kelas IX-1 SMP Lab Undiksha Singaraja yang dilakukan oleh guru sudah sesuai dengan langkah-langkah pada pembelajaran dalam RPP yang telah disusun guru. Dalam kegiatan pembelajaran sudah terdapat pendahuluan, inti, dan juga penutup. Pembelajaran juga berjalan dengan lancar walaupun ada beberapa kendala yang menimpa guru maupun siswa yaitu terkendala sinyal, tetapi guru sudah berusaha menjalankan pembelajaran hingga bisa menutupi kendala tersebut seperti mengejar ketertinggalan siswa dengan membagikan materi, salindia, dan juga video pembelajaran dalam aplikasi Google Classroom yang digunakan guru. Terakhir respons siswa yang telah dikumpulkan peneliti menggunakan aplikasi Google Form berlangsung dengan lancar dan tanpa hambatan. Dari 21 siswa kelas IX-1 yang telah mengumpulkan angket berpendapat bahwasannya pembelajaran sebelum pandemi Covid-19 lebih baik dari pada pembelajaran saat pandemi Covid-19. Diketahui oleh siswa pandemi membuat siswa kesulitan dalam belajar, apalagi banyak kendala yang bermunculan dari sisi siswa seperti terkendala sinyal, materi yang susah dipahami, dan pembelajaran yang tidak menyenangkan seperti sebelumnya. Siswa juga mengharapkan pembelajaran bisa kembali seperti sebelumnya yaitu ketika pandemi belum melanda dunia pendidikan sehingga siswa dapat lebih mudah menyerap materi yang disampaikan guru dan taka da lagi kendala sinyal yang dihadapi siswa. 


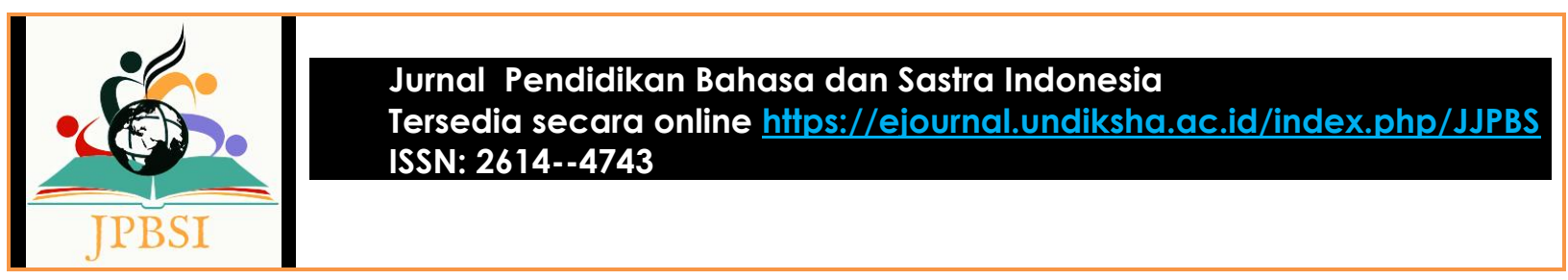

\section{DAFTAR PUSTAKA}

Dewantara, I Putu Mas. 2012. Identifikasi Faktor Penyebab Kesulitan Belajar Keterampilan Berbicara Siswa Kelas VIIE SMPN 5 Negara Dan Strategi Guru Untuk Mengatasinya. Singaraja: Volume 1 Nomor 2(Halaman 1-15) https://ejournalpasca.undiksha.ac.id/index.php/jurnal_bahasa/article/view/355

Handarini, Oktafia Ika dan Wulandari, Siti Sri. 2020. Jurnal Pembelajaran Daring Sebagai Upaya Study From Home (SFH) Selama Pandemi Covid 19. Surabaya: Volume 8, Nomor 3 (496-503) https://journal.unesa.ac.id/index.php/jpap/article/view/8503

Padli, Feri; Rusdi. 2020. Respon Siswa Dalam Pembelajaran Online Selama Pandemi. Makasar: Vol 01 No 3(Halm 1-7) https://ojs.unm.ac.id/SLJ/article/view/14508

Pennington, Tess. 2020. Panduan Kesiapsiagaan Hadapi Virus Corona. Jakarta: PT Elex Media Komputindo.

Putri Bintari, Ni Luh Gede Riwan, Sudiana, I Nyoman, dan Putrayasa, Ida Bagus. 2014. Pembelajaran Bahasa Indonesia Berdasarkan Pendekatan Saintifik (Problem Based Learning) Sesuai Kurikulum 2013 Di Kelas VII SMP Negeri 2 Amlapura. Singaraja: Volume 3 Nomor 1 https://ejournal-pasca.undiksha.ac.id/index.php/jurnal_bahasa/article/view/1185

Roza, Mela Murti. 2012. Pelaksanaan Pembelajaran Sains Anak Taman Kanak-Kanak Aisyiyah Bustanul Athfal 29 Padang. Padang: Volume 1 Nomor 1 (Halm 1-11)

Sangadji, Etta Mamang dan Sopiah. 2010. Metodologi Penelitian. Yogyakarta. Penerbit Andi.

Sanjaya, Wina. 2008. Perencanaan dan Desain Sistem Pembelajaran. Jakarta:Kencana.

Satrianingrum, Arifah Prima dan Prasetyo, Iis. 2021. Jurnal Persepsi Guru Dampak Pandemi Covid19 terhadap Pelaksanaan Pembelajaran Daring di PAUD. Yogyakarta: Volume 5 Issue 1(Halm 633-640) https://obsesi.or.id/index.php/obsesi/article/view/574

Simanjuntak, Sinta Dameria, Imelda. 2018. Respon Siswa Terhadap Pembelajaran Matematika Realistik Dengan Konteks Budaya Batak Toba. Universitas Katolik Santo Thomas: Vol. 4, No. 1

(Halm 81-88) https://jurnal.uisu.ac.id/index.php/mesuisu/article/view/874

Suandi, I Nengah. 2008. Metodologi Penelitian Bahasa. Singaraja: Universitas Pendidikan Ganesha

Uno, Hamzah. 2010. Perencanaan Pembelajaran.Jakarta: Bumi Aksara.

Wahyono, Pancojari; H. Husanah; dan Setia Budi, Anton. 2020. Jurnal Guru profesional di masa pandemi COVID-19: Review implementasi, tantangan, dan solusi pembelajaran daring. Malang:Volume 11 Nomor 1(51-65). https://ejournal.umm.ac.id/index.php/jppg/article/view/12462

Wendra, I Wayan. 2019. Buku Ajar Penulisan Karya Ilmiah. Singaraja: Undiksha.

Widhiarso, Wahyu. 2012. Deteksi Dan Eksplorasi Kesesatan Respons Siswa Pada Skala Motivasi Berprestasi. Yogyakarta: Volume 45, Nomor 2 (Halm 118-129) https://ejournal.undiksha.ac.id/index.php/JPP/article/view/1825

Wirahyuni, Kadek. 2017. Meningkatkan Minat Baca Melalui Permainan Teka Teki Silang Dan 'Balsem Plang'. Singaraja: Vo.3, No.1 (Halm 1-11) https://ejournal.undiksha.ac.id/index.php/AP/article/view/12731

Yolandasari, Mega Berliana.2020. Efektivitas Pembelajaran Daring Dalam Pembelajaran Bahasa Indonesia Di Kelas Ii A Mi Unggulan Miftahul Huda Tumang Cepogo Boyolali. . Boyolali http://e-repository.perpus.iainsalatiga.ac.id/9550/

Copyright holder: (C Lestari, D. F. (2021)

Fist publication right: Jurnal Pendidikan Bahasa dan Sastra Indonesia Undiksha 